awarded Hermann Träuble the Ludwig Schunk Prize in 1972 and the German Bunsen Society for Physical Chemistry the Bodenstein Prize in 1975.

The man, just 44 , was called away at the zenith of his career. We shall not

Ian Macpherson, head of the Department of Virology at the Imperial Cancer Research Fund Laboratories, London, died on September 11, 1976 at the age of 46 , in the middle of a distinguished career. He was married with three children.

Macpherson was born and educated in Scotland, as a Foundation Scholar at George Herriots, and after at Edinburgh University, leading to a Carnegie Fellowship and a Ph.D. in virology in 1955. He then worked at the Microbiological Research Establishment, Porton, for four years before moving to Glasgow in 1959. After a year in the Department of Genetics, he became a founder member of the new Institute of Virology and of the Medical Research Council's Experimental Virus Research Unit. Except for a year as an Eleanor Roosevelt Cancer Fellow at the Wistar Institute, Philadelphia, he remained in Glasgow until 1968 when he

The eminent organic chemist George $\mathbf{0}$. Curme, Jr died on July 28 at his summer home at Oaks Bluff, Massachusetts. $\mathrm{He}$ was born in Mount Vernon, Iowa in 1888 , the son of a professor of German who was also a renowned grammarian. Curme graduated at Northwestern University, then as a graduate student moved from Harvard to the University of Chicago, where he obtained his Ph.D. Next he went to Germany, then the Mecca of organic chemists (it has been said that in the first half of the century all organic laboratories were built pointing towards Berlin) to study under Fritz Haber and Emil Fischer at the Kaiser Wilhelm Institute and the University meet Herman Träuble again in the corridors of the Institute, or be enlivened at our tea colloquia by his burning enthusiasm and swabish charme; we shall not race together down the ski slopes in January, and I

was appointed to the senior staff of the Imperial Cancer Research Fund Laboratories in London to head a substantial department.

Macpherson began to study tumour viruses in Glasgow and it was for his unique and pioneering contributions to the study of virus transformed cells that he will be remembered. Of great importance was the isolation of the first line of cultured cells (BHK 21 cells) which could be used for precise quantitative evaluation of the transformation process, and which allowed direct comparison of transformed and untransformed cells from the same clonal population. Then came the discovery, with Montagnier, of the agar suspension assay system, which, with its various modifications, is of profound importance in tumour cell biology. Macpherson also isolated the first revertants of transformed cells, thus paving the way for the use by others

\section{of Berlin.}

On returning to America he worked from 1914-1920 as a research fellow at the Mellon Institute, and it was here that he started on the work which founded the synthetic alipathic organic chemistry industry in America. (Aliphatic chemistry deals with chain-like compounds of carbon, as opposed to aromatic chemistry which deals with ring compounds.) $\mathrm{He}$ initially sought a method for the commercial manufacture of acetylene; he later widened his horizons to many other alipathic compounds.

In 1917 he started to work for Union Carbide, with whom he was to remain (eventually becoming a director) until shall never have another chance of digging with him for fossils in California. Certainly, death is an integral part of life. But this insight cannot take the pain away.

Manfred Eigen

of this important method for studying the transformed cell phenotype. In recent years Macpherson and his colleagues in London concentrated on the altered surface chemistry of transformed cells, and in particular developed the use of conditional mutants for elucidating the role of the virus.

Through Macpherson's wide reputation, his laboratory attracted visitors from far and near. He lead his group from the laboratory bench, not only by his originality and knowledge but by his experimental ability. Those associated with him soon discovered another aspect of his character as well-his impish sense of humour. This was often expressed in remarkable collages in which he delighted to ridicule any pompous and unjustified aggrandisment.

Ian Macpherson's hobby was golf, in which he also excelled, and it was on the golf course that he died.

his retirement. From the Union Carbide laboratories in 1925 he announced the discovery of a process to make ethylene glycol, which soon replaced alcohol for use as an antifreeze in cars' radiators, and which rapidly developed into a multi-million dollar industry. Dr Curme continued his research, producing a new synthesis of ethyl alcohol, and later playing an important part in the wartime synthetic rubber programme.

Among the many awards he was given was the Willard Gibbs Medal, bestowed on him by the American Chemical Society in 1944 for his fundamental role in bringing "leadership in organic chemistry from Germany to the U.S.A."

\title{
announcements
}

\section{Meetings}

November 17-19, ACTH and Related Peptides: Structure, Regulation and Action, New York (Mr Charles Roarty, The Barbizon-Plaza Hotel, 106 Central Park South, New York, New York 10019).

Winter Gordon Research Confcrences: January 3-7, Deformation and Failure Mechanics in Polymer Composites; Bacterial Cell Surfaces.

January 10-14, Polymers; Organic Thin Films and Solid Surfaces.
January 17-21, Electrochemistry; Agricultural Science.

January 24-28, Chemical Oceanography.

January 31-February 4, Hormone Action.

(Alexander M. Cruickshank, Director Gordon Research Conferences, Pastore Chemical Laboratory, University of Rhode Island, Kingston, Rhode Island 02881).

June 1-3, Frequency Control, Atlantic City, New Jersey (Deadline for abstracts: January 21) (Commander,
US Army Electronics Command, ATTN: DRSEL-TL-MF (Dr J. R. Vig), Fort Monmouth, New Jersey 07703).

September 5-9, Precise Electrical Measurements, Brighton, Sussex (Conference Secretary, The IEE, Savoy Place, London WC2R 0BL).

September 5-10, Geochronology, Cosmochronology and Isotope Geology, Pisa, Italy (Deadline for abstracts: May 15) (Gabriella Bonadonna, C.N.R.Laboratorio di Geochronologia, Via Cardinale Maffi, 36, 56100 Pisa, Italy). 